Ethos (Jurnal Penelitian dan Pengabdian Masyarakat): 55-62

\title{
Kajian Faktor-Faktor Penyebab Timbulnya Pasar Minggu di KaWasan BANDUNG TIMUR
}

The Study of Incidence Factors Contributing to the PASAR MingGu AT BAndung Timur Region

\author{
${ }^{1}$ Lely Syiddatul Akliyah, ${ }^{2}$ Astri Mutia Ekasari, ${ }^{3}$ Odah
}

1,2,3 Program Studi Perencanaan Wilayah \& Kota, Fakultas Teknik, Universitas Islam Bandung,
Jl.Tamansari No. 1 Bandung 40116
E-mail: ${ }^{1}$ lelysyidddatul@gmail.com, ${ }^{2}$ astrimutia_ekasari@yahoo.com, ${ }^{3}$ odah2004@gmail.com

\begin{abstract}
The proliferation of Pasar Minggu in Bandung, especially in the area of Bandung Timur raises some positive and negative impacts. Among the negative impacts is the traffic jam, a heap of waste generated from trade activity, and environmental conditions were filthy and chaotic. If this is allowed to continue, the growth in the market on this week could be growing uncontrollably. As an initial study, it is necessary to explore the factors causing the Pasar Minggu in The Bandung Timur Region. Thereby expect to further of this research can be structured strategies to minimize the negative impact of market developments this week. Selected two sites in Bandung Timur Region namely Metro Region-Margahayu Raya and Jalan Ibrahim Adjie corridor area. The method used is descriptive quantitative data collection methods to survey the secondary data and the primary to the field using a questionnaire and interviews. Found the factors causing the Pasar Minggu in the Bandung Timur Region include: low cost of regular payments, a strategic location near the settlements, ease of transportation to reach the area of trade, traders generally stay not far away from the Sunday market, and the turnover of earning is big enough.
\end{abstract}

Keywords: Factors, Pasar Minggu, Bandung Timur Region

\begin{abstract}
Abstrak. Semakin menjamurnya keberadaan pasar minggu di Kota Bandung, khususnya di Kawasan Bandung Timur menimbulkan beberapa dampak positif dan negatif. Diantara dampak negatif yang ditimbulkan adalah kemacetan, timbulan sampah yang dihasilkan akibat kegiatan jual-beli, dan kondisi lingkungan yang kotor dan semrawut. Jika hal ini dibiarkan terus berkembang, maka pertumbuhan pasar minggu ini bisa menjadi semakin berkembang tak terkendali. Sebagai penelitian awal, maka diperlukan kajian mengenai faktor-faktor penyebab timbulnya pasar minggu di Kawasan Bandung Timur. Diharapkan dari penelitian ini dapat disusun strategi-strategi yang dapat meminimalisir dampak negatif dari perkembangan pasar minggu ini. Dipilih dua lokasi di Kawasan Bandung Timur yaitu Kawasan Metro-Margahayu Raya dan Kawasaan Koridor Jalan Ibrahim Adjie. Metode penelitian yang digunakan adalah deskriptif kuantitatif dengan metode pengumpulan data adalah melakukan survey data-data sekunder dan primer ke lapangan menggunakan alat kuesioner dan wawancara. Ditemukan faktor-faktor penyebab timbulnya pasar minggu di Kawasan Bandung Timur diantaranya: murahnya biaya iuran rutin, lokasi yang strategis dekat permukiman penduduk, kemudahan sarana transportasi untuk mencapai lokasi berdagang, pedagang umumnya tinggal tidak jauh dari pasar minggu, dan omset penghasilan cukup besar.
\end{abstract}

Kata kunci: Faktor-Faktor, Pasar Minggu, Kawasan Bandung Timur 


\section{Pendahuluan}

Kota Bandung adalah salah satu kota di Indonesia yang berpenduduk padat dengan laju pertumbuhan penduduk dari tahun ke tahun yang semakin meningkat. Namun, laju pertumbuhan ekonominya mengalami perlambatan dari tahun 2013 sebesar 8,87 \% menjadi 7,69 \% pada tahun 2014 (BPS Kota Bandung, 2014). Namun demikian, kondisi ini tidak hanya terjadi di Kota Bandung saja tetapi secara umum kondisi ekonomi di Indonesia mengalami krisis ekonomi global akibat nilai mata uang dunia yang semakin naik. Hal ini juga tentunya berdampak terhadap kondisi ekonomi masyarakat Kota Bandung. Salah satu dampaknya adalah timbulnya sektor-sektor ekonomi informal yang memiliki konsumen sangat luas akibat rendahnya daya beli masyarakat.

Salah satu sektor informal yang ada adalah pedagang kaki lima (PKL) yang berjualan menggunakan prasarana trotoar dan badan jalan. Diantara bentuk kegiatan perdagangan yang muncul di Kota Bandung ini adalah adanya kegiatan jual beli yang dilakukan oleh PKL yang dikenal dengan istilah 'pasar minggu' yang dilakukan setiap Hari Minggu. Pasar-pasar ini bermunculan secara spontan di beberapa kawasan di Kota Bandung.

Salahsatu lokasi pasar minggu yang ada di Kota Bandung, khususnya bandung Timur yaitu pasar minggu yang berada di Kawasan Metro - Margahayu Raya, serta PKL yang berada di daerah sekitar Kantor Samsat (Jl. Ibrahim Adjie). Kedua lokasi tersebut dipilih dalam penelitian ini karena berada dalam lingkungan yang berbeda dan merupakan 2 dari 8 lokasi yang berada di zona kuning PKL di Kawasan Bandung Timur. Kawasan Metro-Margahayu Raya merupakan kawasan permukiman, sementara kawasan Ibrahim Adjie merupakan jalan kolektor yang berbatasan langsung dengan jalan arteri primer (Jalan Soekarno Hatta). Selain itu, dua lokasi ini merupakan pasar minggu yang muncul paling awal di sekitar Kawasan Bandung Timur.

Keberadaan pasar minggu ini dapat memberikan hal positif dan negatif. Hal positif yang ada diantaranya: letaknya yang tidak jauh dari permukiman warga sekitar dan harga yang relatif lebih murah. Namun dampak negatif yang dihasilkan pun lebih besar ketimbang dampak positif yang dihasilkan oleh adanya pasar minggu tersebut, diantaranya kemacetan, kerusakan lingkungan, dan timbulan sampah yang dihasilkan. Jika hal ini dibiarkan akan menyebabkan terganggunya berbagai macam aktivitas kegiatan dan kerusakan lingkungan di Kota Bandung.

Untuk mengetahui faktor apa saja yang menimbulkan menjamurnya pasar-pasar minggu ini, maka dilakukan kajian mengenai faktor-faktor yang menyebabkan timbulnya pasar minggu di Kawasan Bandung Timur. Output penelitian ini diharapkan dapat menjadi masukan untuk membuat kebijakan agar keberadaan pasar minggu tidak semakin menjamur dan semakin tertata sehingga keamanan, ketertiban, dan kenyamanan masyarakat sekitar kawasan pasar minggu tetap terjaga.

Dari berbagai literatur, belum ada definisi mengenai pasar minggu atau yang dikenal masyarakat dengan istilah 'Pasar Kaget'. Pasar minggu/pasar kaget yang dimaksud dalam penelitian ini ialah jenis pasar yang ada setiap hari-hari tertentu (pada umumnya hari minggu), menggunakan sarana yang tidak permanen (temporer), prasarana yang digunakan biasanya berupa trotoar jalan atau tempat parkir, waktu berjualan hanya dalam beberapa jam saja (dibatasi). Salahsatu kajian mengenai pasar kaget dilakukan oleh Putra (2010) untuk mengetahui permasalahan yang muncul akibat dari keberadaan dan perkembangan pasar kaget Rawajati terhadap permukiman sekitar pasar kaget. Adapun variabel yang digunakannya diantaranya: Fisik Lingkungan, Pelayanan Pasar, dan Fisik Lingkungan Sosial. Sementara variable yang digunakan 
dalam penelitian ini adalah: Pengalaman Berdagang di Lokasi (Pasar) lain, Informasi Keberadaan Pasar Minggu,Alasan Berdagang di Pasar Minggu, Penghasilan Yang Didapat, Tingkat Kemudahan Biaya Sewa/Iuran, Waktu Berdagang, Alasan Pemilihan Lokasi, Hubungan Antar PKL, dan Pembatasan Jumlah Lapak.

Adapun berdasarkan kebijakan Peraturan Walikota Bandung No. 888 Tahun 2012 tentang Petunjuk Pelaksanaan Peraturan Daerah Kota Bandung Nomor 04 Tahun 2011 Tentang Penataan dan Pembinaan Pedagang Kaki Lima dikaitkan dengan kondisi pasar minggu saat ini dapat dilihat pada tabel 1.

Tabel 1. Review Peraturan Walikota Bandung No. 888 Tahun 2012 dengan Kondisi Pasar Minggu Saat Ini

\begin{tabular}{|c|c|}
\hline Peraturan Walikota Bandung No. 888 Tahun 2012 & Kondisi Pasar Minggu Saat Ini \\
\hline $\begin{array}{l}\text { Pasal } 21 \\
\text { Jalan Ibrahim Adjie (Samping Samsat) dan Komplek Metro Margahayu Raya } \\
\text { adalah } 2 \text { dari } 27 \text { lokasi PKL yang berada dalam Zona Kuning. } \\
\text { PKL diperbolehkan berdagang dengan ketentuan: } \\
\text { a. Khusus pada hari minggu waktu berdagang dibatasi mulai jam } 04.00 \text { WIB } \\
\text { sampai dengan jam } 10.00 \text { WIB; } \\
\text { b. Khusus untuk aneka komoditi waktu berdagang dibatasi mulai jam } 10.00 \\
\text { WIB sampai dengan jam } 18.00 \text { WIB. }\end{array}$ & $\begin{array}{l}\text { - Waktu berjualan biasa dilakukan dari pukul } 06.00-12.00 \text { WIB. } \\
\text { - Pengguna jalan merasakan ketidaknyamanan akan kegiatan PKL ini, } \\
\text { sempat terjadi penolakan dari warga Metro yang rumahnya berada di } \\
\text { sekitar pasar minggu ini. }\end{array}$ \\
\hline $\begin{array}{l}\text { Pasal } 26 \\
\text { Pengaturan mengenai sarana berdagang sebagai berikut: } \\
\text { a. Ukuran tempat berdagang PKL, paling besar berukuran } 2 \times 2 \text { meter, } \\
\text { b. Ukuran tempat berdagang khusus untuk PKL kuliner paling besar } \\
\text { berukuran } 2 \times 3 \text { meter, } \\
\text { c. Ukuran tempat berdagang untuk tenda makanan/lesehan termasuk } \\
\text { gerobaknya paling luas } 10 \text { meter persegi; } \\
\text { d. Ukuran tempat berdagang berupa Gerobak paling panjang } 1,20 \text { meter, } \\
\text { paling lebar } 0,80 \text { meter dan paling tinggi } 1,20 \text { meter, } \\
\text { e. Ukuran tempat berdagang bagi PKL yang berada di trotoar tertentu yang } \\
\text { telah ditetapkan/ditunjuk/diizinkan oleh Walikota, tidak boleh melebihi } 2 / 3 \\
\text { lebar trotoar, sehingga trotoar masih memungkinkan di gunakan oleh para } \\
\text { pejalan kaki. }\end{array}$ & $\begin{array}{l}\text { - Ukuran tempat berdagang sangat bervariasi, dengan sebaran yang tidak } \\
\text { dapat dibatasi. } \\
\text { - Trotoar digunakan untuk berjualan PKL, sehingga pejalan kaki dan } \\
\text { pembeli menggunakan badan jalan. }\end{array}$ \\
\hline 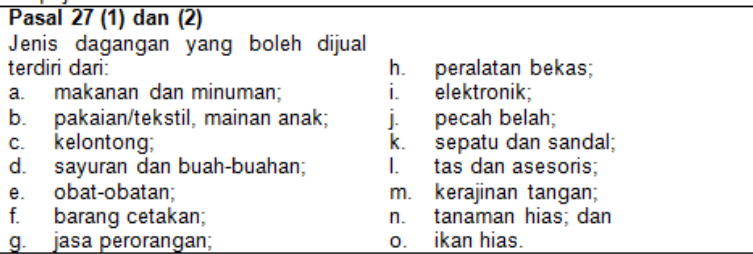 & $\begin{array}{l}\text { - Berdasarkan jenis dagangannya, di kedua lokasi penelitian sudah sesuai. } \\
\text { - Beberapa PKL ada yang menjual jenis dagangan berupa hewan } \\
\text { peliharaan seperti burung, hamster, dan sebagainya. Hal ini tentunya } \\
\text { tidak seusia dengan Perwal tersebut. Mengacu pada Pasal } 27 \text { ayat (3), } \\
\text { seharusnya pindah ke lokasi berjualan yang sesuai peruntukkannya } \\
\text { seperti Pasar Burung Sukahaji. }\end{array}$ \\
\hline
\end{tabular}

\section{Metodologi Penelitian}

Metode penelitian yang digunakan adalah deskriptif kuantitatif dengan metode pengumpulan data adalah melakukan survey data-data sekunder dan primer ke lapangan menggunakan alat kuesioner dan wawancara.

\section{Hasil dan Pembahasan}

Hasil kajian mengkaji faktor-faktor yang mempengaruhi timbulnya pasar minggu di Bandung Timur berdasarkan beberapa variabel yang digunakan adalah sebagai berikut:

\section{Pengalaman Berdagang di Lokasi (Pasar) lain}

Sebagian besar pedagang yang berjualan dipasar mingguan ternyata belum pernah berjualan di pasar lain, dan mereka hanya berjualan di pasar kaget seperti ini, yaitu sebanyak $67 \%$. Namun banyak juga para pedaganga yang memang sudah lama 
menjadi PKL artinya pernah berjualan dipasar lain seperti di Komplek Pindad, Tegallega, Buah Batu, Sekelimus, Pasar Dunungan, Warta, dan lain sebagainya, yaitu sebanyak 33\%. Dengan demikian, munculnya Pasar Minggu di Kawasan Bandung Timur tidak berkaitan dengan pengalaman pedagang apakah pernah berdagang sebelumnya atau tidak. Kegiatan itu baik dilakukan di pasar tradisional maupun pasar minggu lainnya.

\section{Informasi Keberadaan Pasar Minggu}

Sebagian besar pedagang ternyata mendapat informasi tempat berdagang di pasar mingguan dari teman yaitu 50\%, sebagian kecil dari saudara. Namun banyak juga yang menjawab dari sumber lain, yaitu diperoleh sendiri dan dari warga disekitar rumah sebanyak 36,7\%. Kemunculan pasar minggu ini, ternyata berdasarkan wawancara mendalam yang dilakukan terhadap beberapa orang pedagang umumnya dilakukan oleh pedagang yang ada di lokasi ini juga namun pada waktu yang berbeda. Misalnya pada hari Selasa pagi dan Sabtu sore, mereka ada yang berjualan di Pasar Kaget Cidurain Utara, hari lainnya berdagang di Pasara Rametuk Babakan Jati, dan sebagainya sehingga dalam seminggu mereka bisa bergant-ganti lokasi berdagang.

\section{Alasan Berdagang di Pasar Minggu}

Motivasi berdagang tentunya ingin memperoleh tambahan penghasilan atau untung yang besar, namun ada juga responden yang menjawab ingin meramailkan saja atau sekedar mengisi waktu yaitu sebanyak $12 \%$, sisanya adalah memperluas usaha $5 \%$.

\section{Penghasilan Yang Didapat}

Ternyata rata-rata omset yang diperoleh para pedagang tidak lah terlalu besar, 95\% pedagang memperoleh pendapatan kotor sekitar Rp. 500.000- Rp. 1.000.000/hari , meskipun ada 5\% yang memperoleh pendapatan rata-rata Rp. 1.500.000-Rp. 2.500.000.

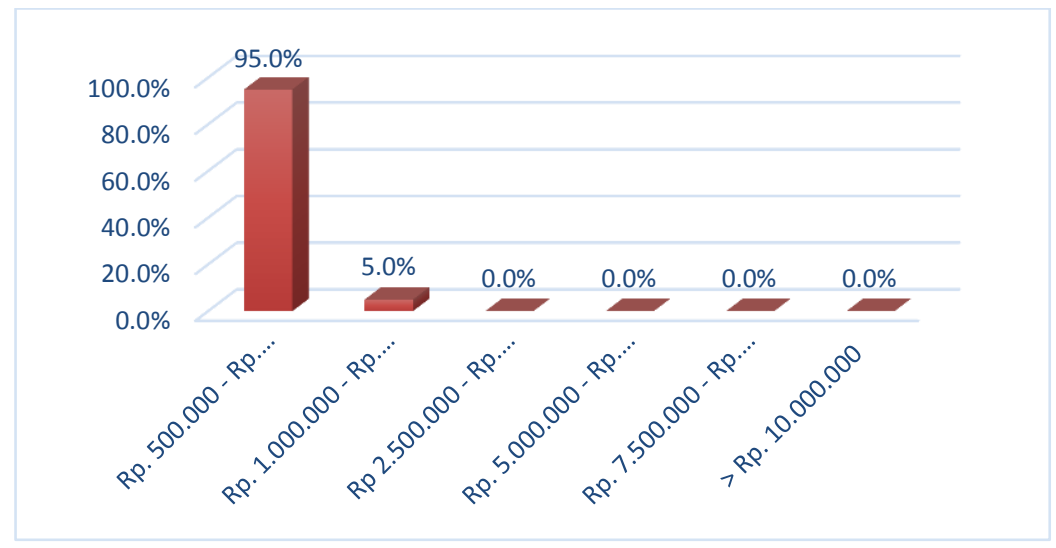

Gambar 1. Rata-rata Omset Per Hari

\section{Tingkat Kemudahan Biaya Iuran}

Sebanyak 73,3\% para pedagang membayar iuran untuk berjualan pada pilihan lain-lain yaitu kepada preman sebagai pengelola sekaligus penjaga kemanan pasar, 
termasuk di dalamnya ada petugas parkir. Hanya sedikit yang membayar kepada petugas retribusi dan mungkin petugas tersebut juga tidak legal.

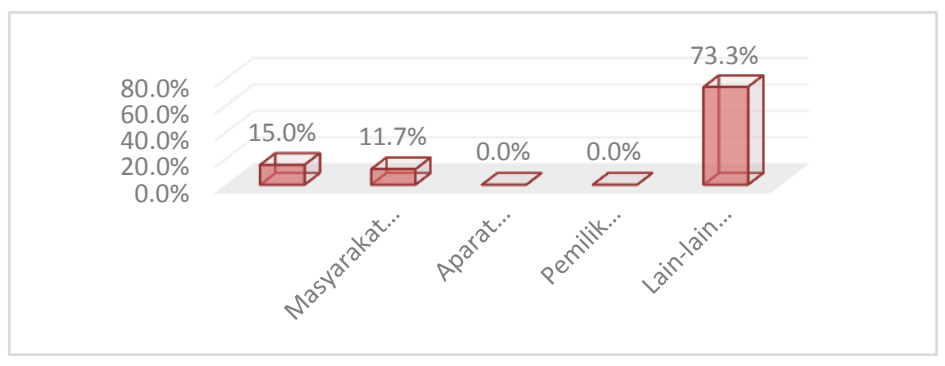

Gambar 2. Tempat Pembayaran Iuran Rutin

Biaya iuran rutin yang dibayarkan sangat murah yaitu hanya Rp. 5.000 untuk setiap kali berjualan, meskipun ada beberapa yang menjawab membayar hingga Rp.15.000. Perbedaan besarnya iuran yang dibayarkan mungkin ditentukan oleh besarnya lapak yang ditempati oleh pedagang serta tingkat keramaian.

\section{Waktu Berdagang}

Waktu berjualan para pedagang dimulai dan diakhiri serentak yaitu pukul 06.0012.00. Kondisi ini kaena pedagang memang berjualan hanya dalam satu hari dan bukan di area pasar, sehingga dibatasi waktunya agar tidak mengganggu ketertiban umum.

\section{Alasan Pemilihan Lokasi}

Pada pilihan alasan memilih lokasi berjualan, responden boleh memilih jawaban lebih dari satu. Sebagian besar pedagang menyatakan memilih lokasi berdagang karena dekat/mudah dijangkau/strategis (100\%). Selain itu banyak juga para pedagang yang menjawab karena kemudahan sarana dan prasarana, banyak pembeli dan dekat dengan tempat tinggalnya.

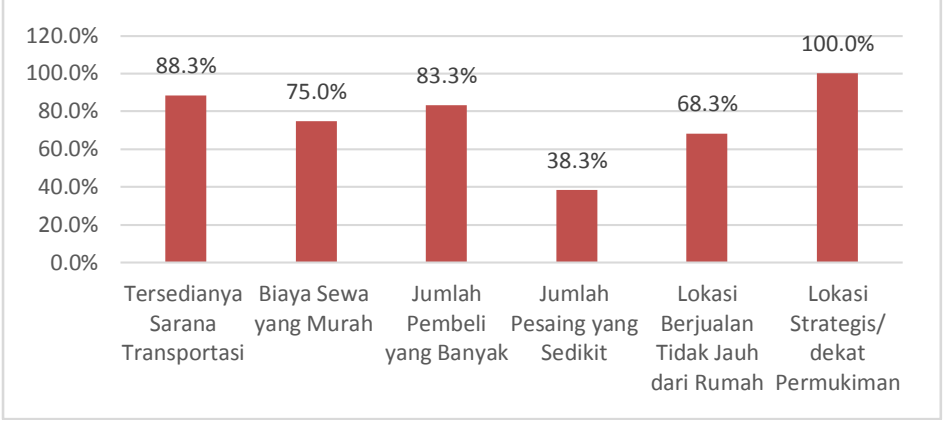

Gambar 3. Alasan Pemilihan Lokasi Berdagang

Lokasi yang strategis, tersedianya sarana transportasi, jumlah pembeli yang banyak, dan biaya sewa yang murah merupakan faktor yang dominan menimbulkan munculnya pasar minggu di Kawasan Bandung Timur. Sementara faktor jumlah pesaing berupa pedagang dengan jenis dagangan yang sama tidak berpengaruh terhadap timbulnya pasar mingguan. 


\section{Hubungan Antar PKL}

Ternyata antara sesama PKL saling membangun komunikasi dan berbagi informasi, hal ini dapat dilihat pada grafik dibawah ini,dimana $66,7 \%$ responden menjawab memiliki hubungan, artinya tidak sekedar berjualan tetapi juga membangun pertemanan. Hal tersebut dapat dilihat pada grafik dibawah ini, ternyata informasi berdagang diperoleh dari sesama pedagang dan mereka memiliki jadwal berdagang setiap harinya di tempat yang berbeda-beda.

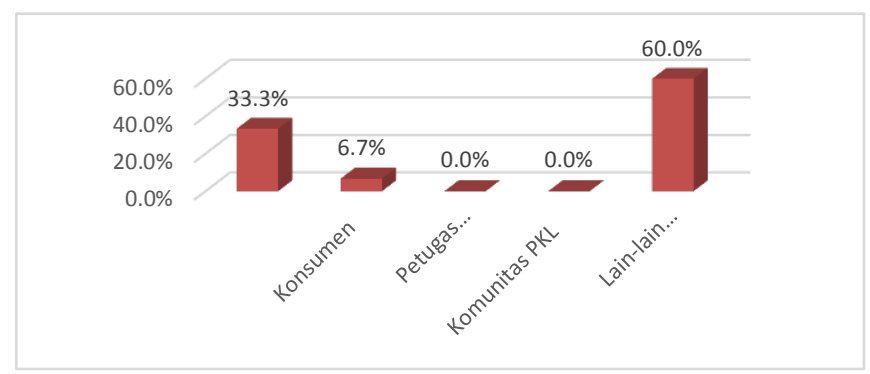

Gambar 4. Sumber Informasi Berdagang

\section{Pembatasan Jumlah Lapak}

Sebagian besar para pedagang ternyata tidak dibatasi lapak untuk berjualan, artinya satu orang boleh memiliki lapak lebih dari satu. Namun demikian, jawaban ini tidak kosisten karena 31,7\% responden menjawab dibatasi. Selain pembatasan jumlah lapak, para pedagang juga memiliki aturan tidak tertulis, antara lain:

[1]. Tidak boleh mendekati bahu jalan raya

[2]. Harus tertib

[3]. Membayar iuran anggota

[4]. Membayar THR lebaran

[5]. Tidak boleh masuk area permukiman

[6]. Menjaga kebersihan

[7]. Tidak melebihi jam $12.00 \mathrm{WIB}$

Pembayaran iuran anggota dan THR dilakukan oleh PKL di Jalan Ibrahim Adjie yang memiliki kartu tanda pengenal.

Dari hasil kuesioner yang disebar, ternyata berjualan di pasar mingguan bukan berarti tanpa masalah. Seringkali para pedagang bermasalah dengan pengurus dalam hal kebebasan memilih lapak berdagang dan ukuran lapak yang terlalu kecil. Selain itu, tidak jarang sering terjadi cekcok dengan pedagang lain, dengan satpol PP, pemalakan oleh preman, dan bentrok dengan warga disekitar area berdagang.

Meskipun menyadari kehadiran mereka adalah illegal, namun hampir semua responden berharap ada ketertiban dan keamanan, khususnya dari pemalakan preman. Hal yang menaarik adalah sebenarnya para pedagang berharapkeberadaan mereka berjualan dapat dilegalkan, mendapat izin dan jaminan keamanan serta kebersihan dan kerapihan. 


\section{Kesimpulan}

Berdasarkan data, informasi, dan hasil analisis didapatkan bahwa karakteristik pasar minggu, baik yang berada di Metro Margahayu Raya maupun di jalan Ibrahim Adjie, pada umumnya menjual jenis barang dagangan seperti pakaian, aksesoris, makanan, minuman, sayuran, buah-buahan, dan barang kelontongan.Karakteristik Pedagang yang berjualan di pasar minggu, dilihat dari tingkat pendidikannya, sebanyak 36,67\% memiliki tingkat pendidikan SMP dan 31,67\% dengan pendidikan terakhir SMA. Berdasarkan hasil review terhadap kebijakan terkait pedagang kaki lima di Kota Bandung, diketahui bahwa ada beberapa pelanggaran yang terjadi di pasar minggu yang diteliti. Saat ini lokasi pasar minggu tersebut berada di zona kuning, artinya diperbolehkan berjualan di lokasi itu namun ada pembatasan waktu yaitu antara pukul 04.00 hingga 10.00 WIB. Pada pelaksanaannya waktu berjualan biasa dilakukan dari pukul 06.00 hingga 12.00 WIB sehingga pengguna jalan lainnya merasakan ketidaknyamanan akan kegiatan PKL ini. Selain itu, pelanggaran lainnya adalah para pedagang tidak menggunakan tanda pengenal, berdagang menggunakan trotoar, dan ada beberapa penjual yang menjual hewan peliharaan.

Faktor-faktor yang menyebabkan munculnya pasar minggu di Kawasan Bandung Timur diantaranya: murahnya biaya iuran rutin, lokasi yang strategis dekat permukiman penduduk, kemudahan sarana transportasi untuk mencapai lokasi berdagang, pedagang umumnya tinggal tidak jauh dari pasar minggu, dan omset penghasilan cukup besar.

Beberapa tindakan yang disarankan antara lain membina koordinasi yang intensif antar stakeholder yang berkepentingan dalam penertiban pedagang kaki lima atau pasar mingguan. Melakukan sosialisasi yang intensif kepada pedagang kaki lima di lokasi pasar mingguan tentang program penataan pasar minggu, waktu yang diperbolehkan untuk berjualan, menjaga ketertiban umum, dan penanganan sampah oleh masing-masing PKL. Menerapkan kebijakan insentif dan disinsentif, berupa :pemberian insentif berupa pembebasan iuran rutin, pemberian penghargaan kepada PKL teladan, penyediaan tempat yang layak, aman, dan nyaman untuk berjualan, dan promosi. Pelanggaran terhadap peraturan dan ketertiban, dapat diberikan disinsentif berupa pengenaan denda, pencabutan izin jualan, hingga sanksi pidana.

\section{Ucapan Terima Kasih}

\section{Daftar pustaka}

Badan Pusat Statistik. [2014]. Produk Domestik Regional Bruto Kota Bandung Tahun 2014. Bandung : BPS.

Pemerintah Kota Bandung. [2012]. Peraturan Walikota Bandung No. 888 Tahun 2012 tentang Petunjuk Pelaksanaan Peraturan Daerah Kota Bandung Nomor 04 Tahun 2011 Tentang Penataan dan Pembinaan Pedagang Kaki Lima. Bandung : Pemkot Bandung 
62 | Lely Syiddatul Akliyah, et al.

Putra, Wicak H. [2010]. Keberadaan dan Perkembangan Pasar Kaget Pawajati Jakarta. Tesis tidak dipublikasikan. Semarang : Program Pascasarjana, Magister Teknik Pembangunan Wilayah dan Kota, Universitas Diponegoro. 